\author{
ارزيابى ماندكارى تأثير كاربرد كودهاى آلى، اوره و سولفات روى بر ويزّكىهاى \\ خاك در تناوب كلزا- گندم \\ سميه مرادنيا'، روح اله نادرى "و مهدى نجفى

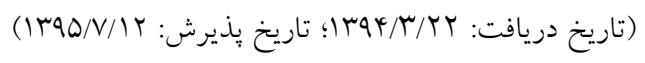

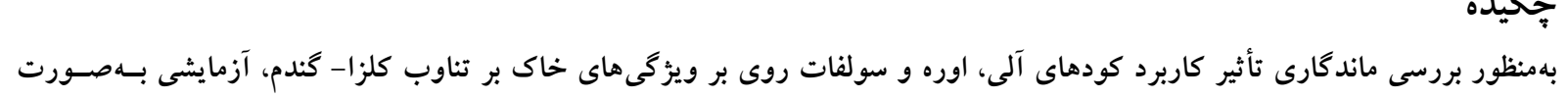

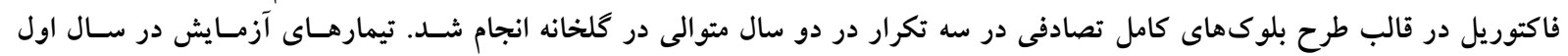

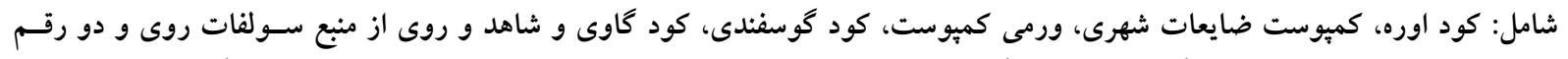

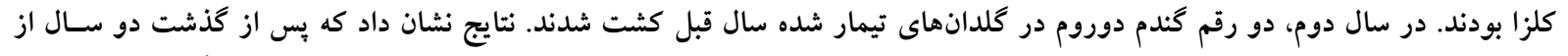

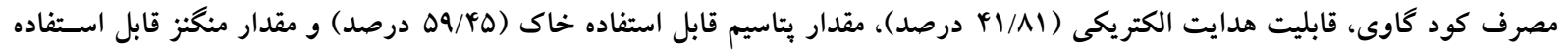

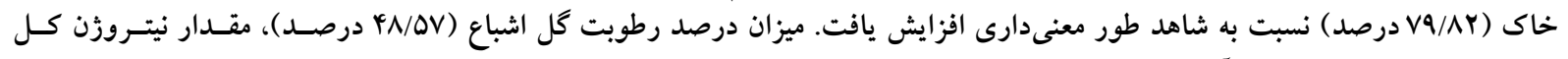

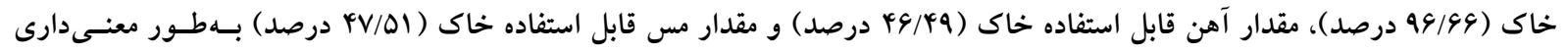

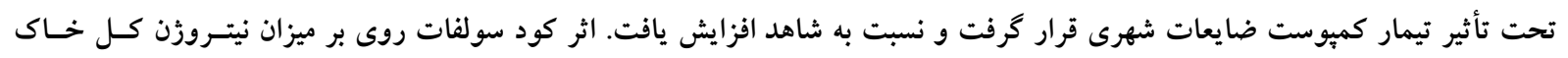

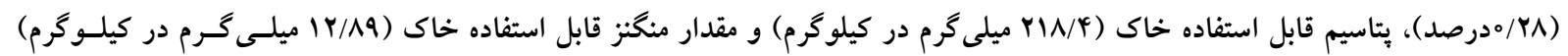

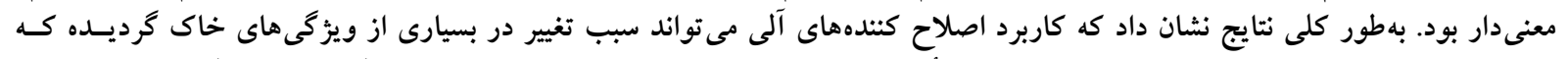

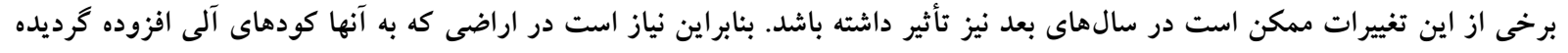

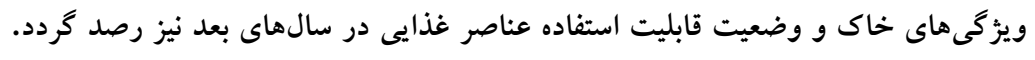

وازههاى كليدى: اصلاح كنندهاى اركانيك، كميوست، كود دامى، كشاورزى بايدار

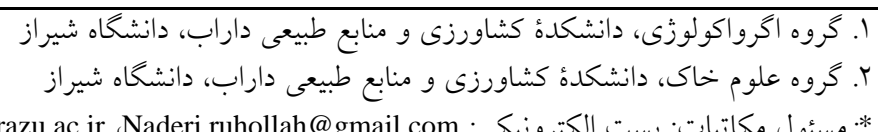

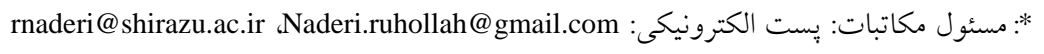


خاك نيز محسوب مىشوند (rا) ). با توجه به اينكه ماده آلى

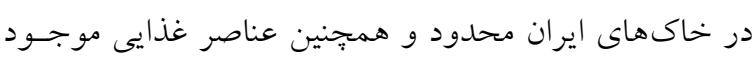

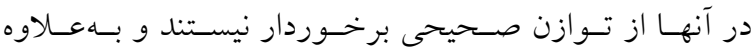

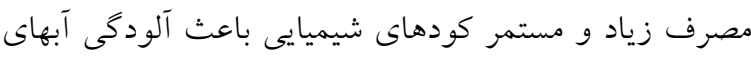

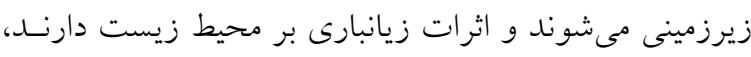

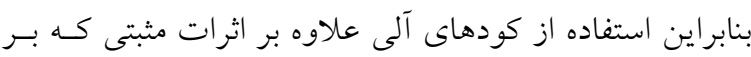

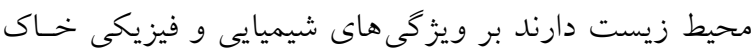

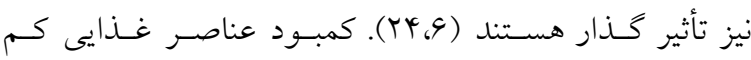
مصرف در كياهان و محصولات زراعى كسترش جهانى دارد.

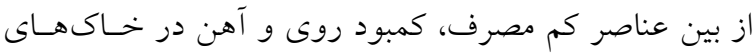

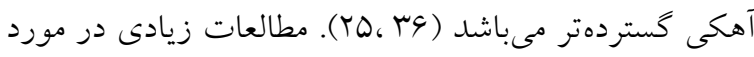
كمبود آهن در خاكهاى آهكى انجام شده است اما مطالعات

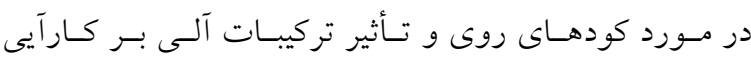
مصرف كودهاى روى كمتر مورد توجسه قـرار كرفتسه اسـت.

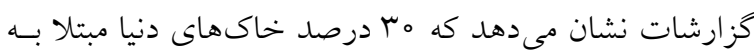
كمبود روى مىباشند. عناصر غذايى كـم مصـرف در اعمـال

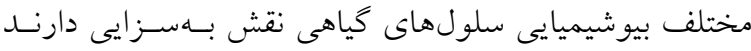

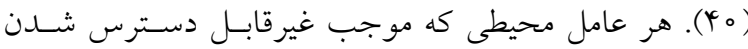
اين عناصر براى گياه گردد، باعث بروز علائم ناشى از كمبود به شكل هاى مختلف از قبيل كاهش عملكرد دانسه و همجتهين كاهش غلظت اين عناصـر در بافت كيـاهى مسىشـود (II).

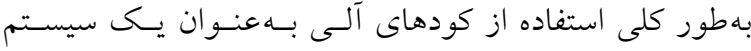
مديريتى صحيح و وايسـار عـلاوه بــر جلـو گيرى از مصـرف

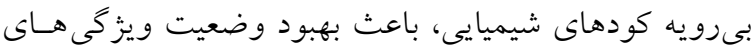
خاك نيز مىشوند. نتايج اين تحقيق مى توانــ در هـيشبينى

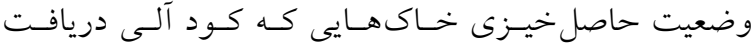
كردهاند مفيد باشد. بهطور كلى مصرف توام كودهـاى آلى و شيميايى همانند سولفات روى از عوامل افزايش عملكــد در تيمارهاى نظام مديريت تلفيقى حاصل خيزى خـاك و تغذيسه كياه مىباشد. لذا اين تحقيق جهت بررسى ارزيابى ماندگارى

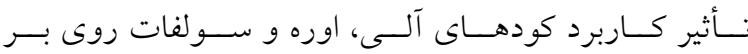
ويزگى هاى خاك در تناوب كلز ا- كندم انجام كرديد.

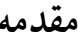

از مهمترين مسائل مؤثر بر توليد بايدار، حفظ حاصـل خيـزى

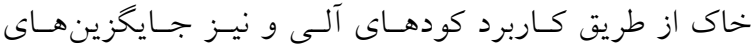

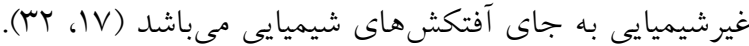
خاكهاى مناطق خشك و نيمهخشى ايران داراى كمبود ماده

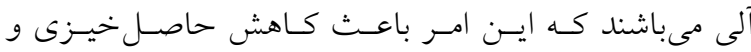
وضعيت نامساعد بعضى خصوصيات شيميايى و فيزيكى اين

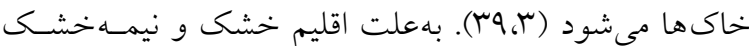

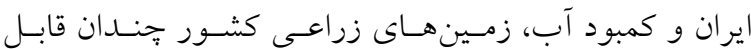

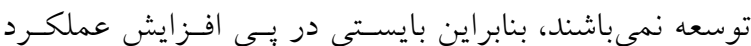

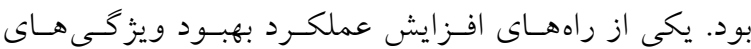

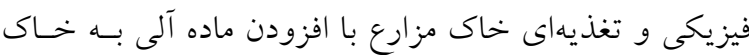

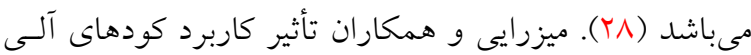

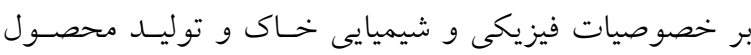
ماده خشى كوجهفرنكى را بررسى كـرده و بـه ايسن نتيجسه

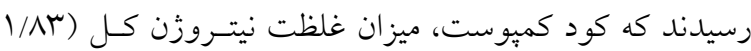
درصد)، فسفر (1/9/9 ميلى گرم در كيلوگرم) و يتاسيم قابـل ميل

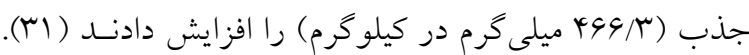

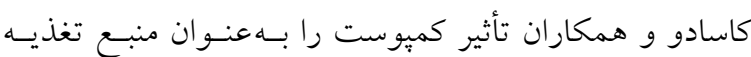

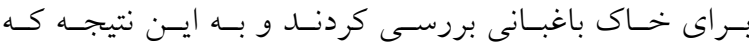

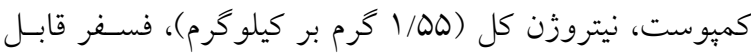

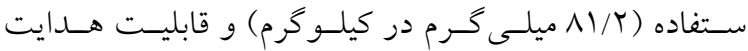

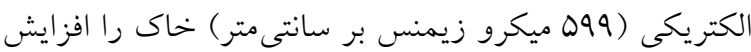

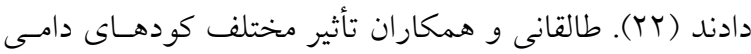
بر كياه جِغندرقند بررسى كردند و نشان دادند كه استفاده از

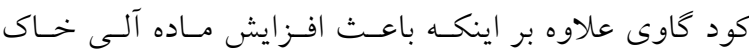
مىشود فعاليت بيولوزيكى خاك را نيز زيـاد مسىكنسـ (10).

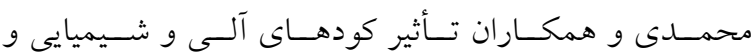
بيولوزيك بر عملكرد و كيفيت دانه كلزا بررسى كردنسـ و بـهـ اين نتيجه رسيدند كه بهطور كلى كمبوست ضايعات شـهرى و كود دامى به علت اثـرات سـازندهاى كـه بـر خصوصسيات فيزيكى و زيستى خاك دارند بهعنوان يكى از اركان بـارورى لئس 


\begin{tabular}{|c|c|}
\hline \multicolumn{2}{|c|}{ جدول ا. برخى ويزگى هاى فيزيكى وشيميايى خاك مورد استفاده } \\
\hline 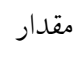 & ويزگكى هاى خاى \\
\hline$V / D Y$ & $\mathrm{pH}$ \\
\hline$\circ / 0$ & ماده آلى (\%) \\
\hline .1019 & 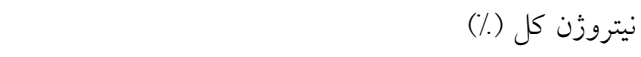 \\
\hline rr & رطوبت اشباع (٪) \\
\hline T/Q9 & قابليت هدايت الكتريكى گل اشباع ( دسى زيمنس بر متر) \\
\hline r。 & فسفر قابل جذب ( ميلى گرم بر كيلوگرم) \\
\hline 140 & يتاسيم قابل جذب ( ميلى گرم بر كيلو گرم) \\
\hline$r / 1 r$ & آهن قابل جذب ( ميلى گرم بر كيلوكرم) \\
\hline $0 / 2$ & روى قابل جذب ( ميلى گرم بر كيلوكرم) \\
\hline $1 / 99$ & مس قابل جذب ( ميلى گرم بر كيلوكرم) \\
\hline r/9 & منكنز قابل جذب ( ميلى گرم بر كيلوكرم) \\
\hline
\end{tabular}

جدول r. برخى خصوصيات شيميايى مواد آلى مصرفى

\begin{tabular}{|c|c|c|c|c|c|c|c|c|}
\hline $\mathrm{Mn}(\mathrm{mg} / \mathrm{kg})$ & $\mathrm{Cu}(\mathrm{mg} / \mathrm{kg})$ & $\mathrm{Fe}(\mathrm{mg} / \mathrm{kg})$ & $\mathrm{EC}\left(\mathrm{dS} \mathrm{m}^{-1}\right)$ & $\mathrm{pH}$ & $\begin{array}{l}\mathrm{K} \\
(\%)\end{array}$ & $\begin{array}{c}\mathrm{P} \\
(\%)\end{array}$ & $\begin{array}{l}\text { T.N } \\
(\%)\end{array}$ & منابع مواد آلى \\
\hline lor & YNI & $1.4 / \Delta$ & $\wedge$ & $9 / 9$ & $0 / \mu r$ & $0 / 94$ & $r / 91$ & كميوست ضايعات شهرى \\
\hline$|r| / \Lambda$ & $1 \cdot 0 / 9$ & $\Lambda 01 / \pi$ & $V / \pi$ & $N / N$ & $\circ / 4 \circ$ & $0 / 90$ & r/QT & ورمى كمبوست \\
\hline $1 / 94$ & $\Gamma / \Lambda$ & $90 N / 9$ & $\varphi / Q 1$ & $V / r_{0}$ & - Q Q T & $\circ / V Y$ & $r / \mu$ & كود كوسفندى \\
\hline $1 T \omega / q$ & $r / \Delta r$ & $9 \circ 4 / r$ & 11 & $\Lambda / V$ & OMY & $0 / A$ & $r / 10$ & كود كاوى \\
\hline
\end{tabular}

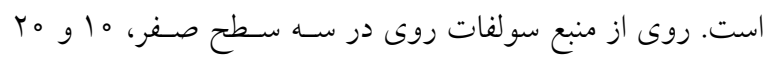

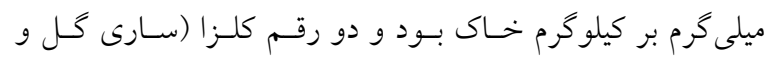

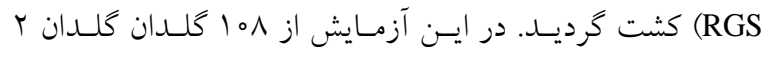

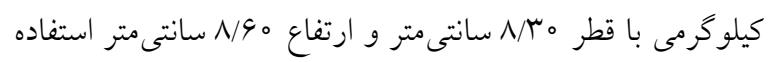

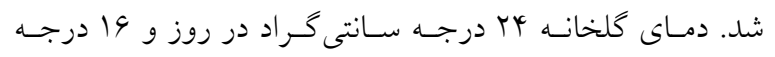

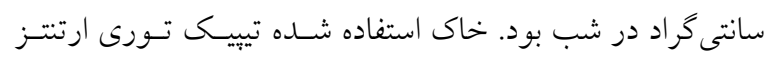
(carbonatic, hyperthermic, TypicTorriorthents Fine-loamy,)

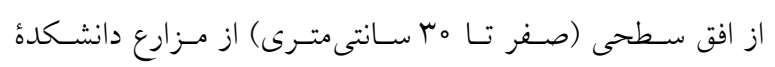

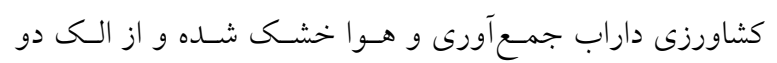

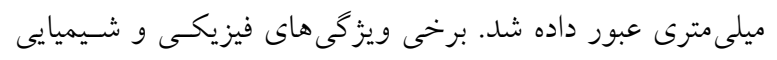

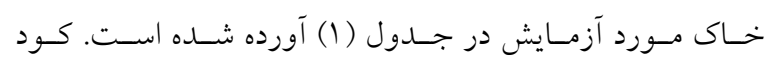
كميوست ضايعات شهرى از كارخانه كميوست سازى اصـفهان و وردو

\section{مواد و روشها - - ماد}

بلهمنظور بررسى اثرات باقىمانده كودهـاى آلى بـر ويزگكى رهـاى

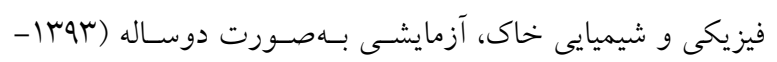

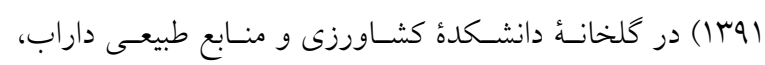

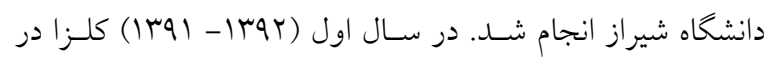

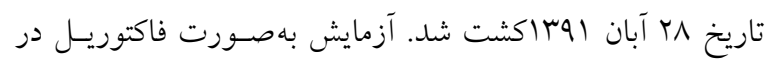

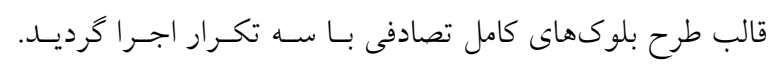

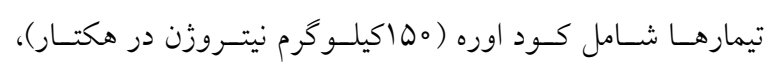

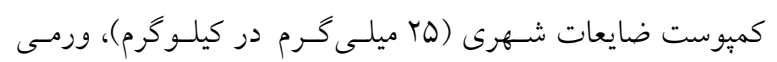

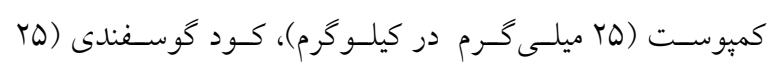

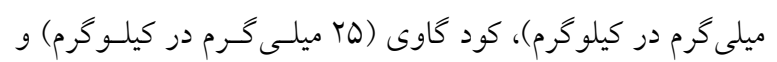

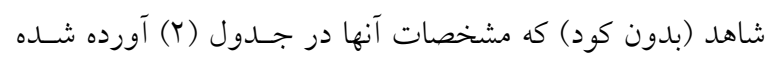




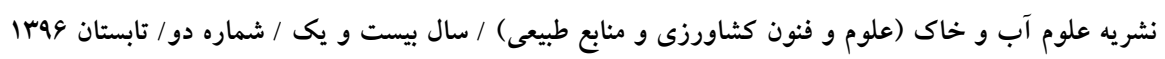

ب

جدوله. ميانخين مربعات عناصر برنياز و برخى ويزّىىهاى فيزيكى خاك تحت تأثير عوامل مختلف مورد مطالعه

\begin{tabular}{|c|c|c|c|c|c|c|}
\hline فسفر & يتاسيم & 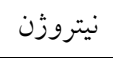 & قابليت هدايت الكتريكى & درصد رطوبت اشباع & درجه آزادى & منابع تغييرات \\
\hline$\varphi / l \mu^{*}$ & $0900 / V Y Y^{* *}$ & $0 / 019^{*}$ & $1 / 090^{* *}$ & $10 / 9 \mu_{0} \mathrm{~ns}$ & r & تكرار \\
\hline$\circ / r \Delta Y^{n s}$ & $\mu \cdot 1 \Lambda / 19 V^{*}$ & O/OYY** & $\circ / \circ \wedge l^{\mathrm{ns}}$ & $r \wedge \backslash / \vee ৭ \varphi^{\mathrm{ns}}$ & r & روى \\
\hline $\mid r / 9 \circ V^{* *}$ & $\mu_{0} 909 / 111^{* *}$ & $0 / 011^{*}$ & Q/GTV & 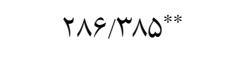 & 0 & كود \\
\hline $1 / 0 \circ V^{n s}$ & $\left.|Y K Y / A|\right|^{\text {ns }}$ & 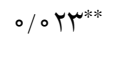 & 1/०r $\mathcal{G}^{* *}$ & $Y \backslash N /\left.Y Y\right|^{\text {ns }}$ & 10 & كود × روى \\
\hline $1 / 001$ & N०V/VYr & $0 / 004$ & OTYV & $9 Q / 414$ & me & خطا \\
\hline
\end{tabular}

\section{نتايج و بحث}

قابليت هدايت الكتريكى خاك (EC)

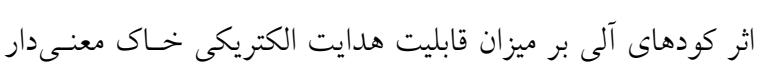

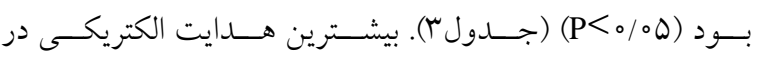

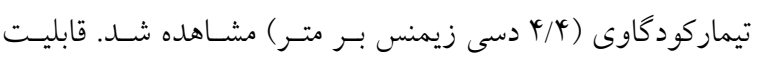

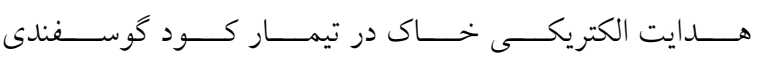

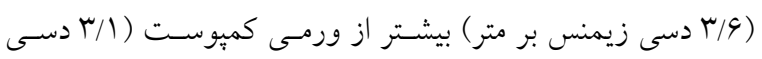

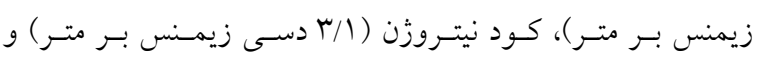

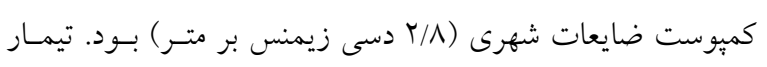

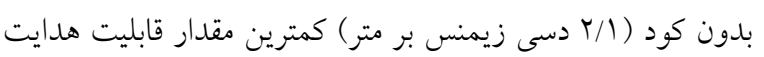

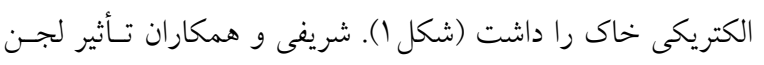

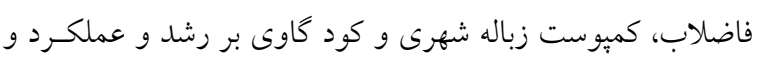
جذب آهن، روى، منخنز و نيكل در كل جعفرى (Tagetes signata

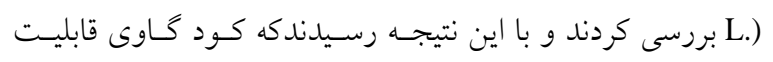

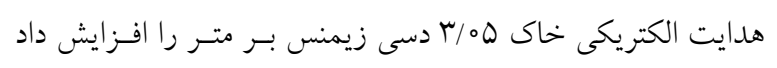

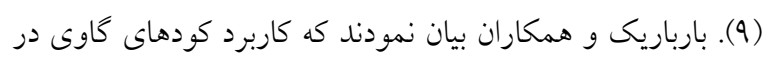

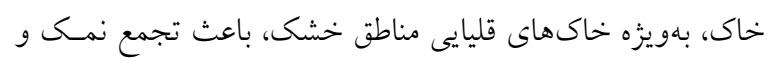
افزايش قابليت هدايت الكتريكى خاك مىشود (19).

\section{درصد رطوبت اشباع}

مصرف كودهاى آلى بر درصد رطوبت اشسباع تـأثير معنسى دارى

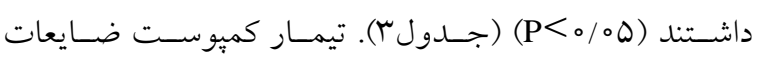

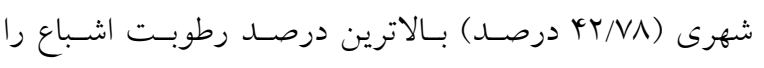

ورمى كمبوست از كارخانه توليد ورمى كمبوست تهيه شد، و كلزا

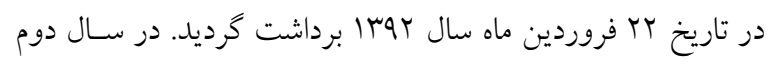

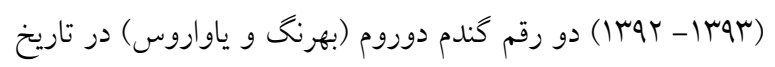

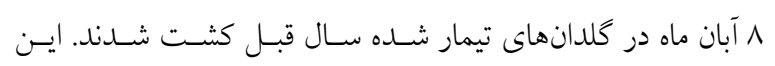
آزمايش نيز در قالب طرح بلوكهاى كامل تصادفى با سه تكرار بودان

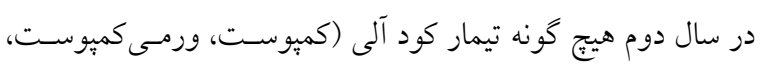

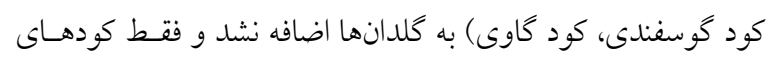

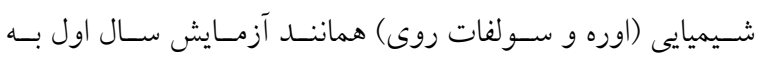

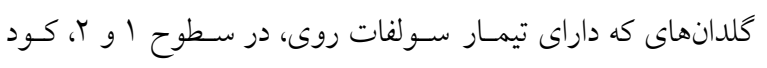

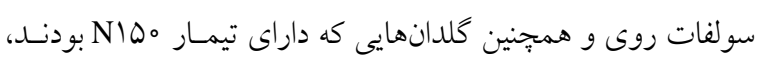

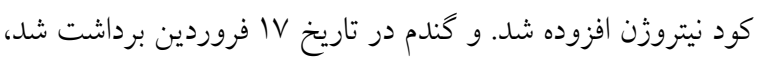

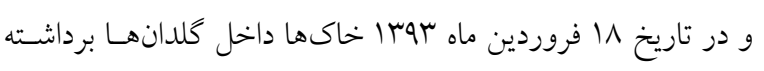

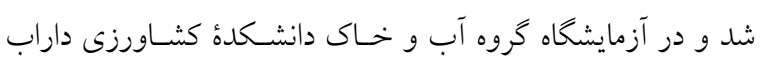

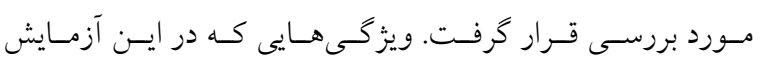

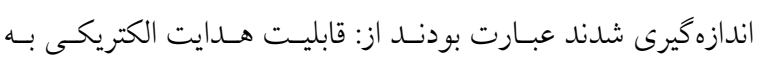

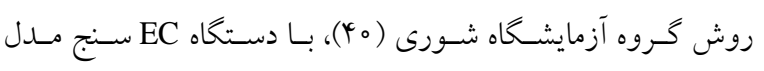

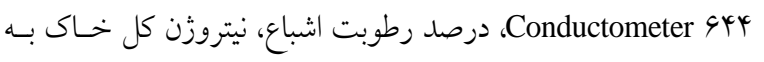

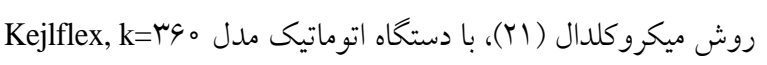

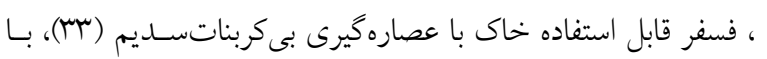

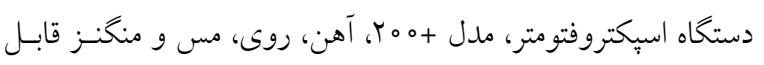

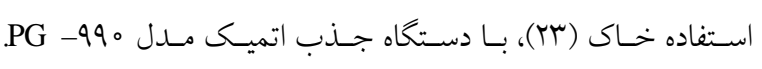

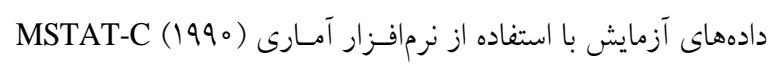

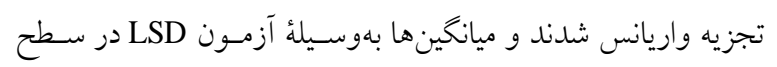
احتمال هـ\% مقايسه شدند. 


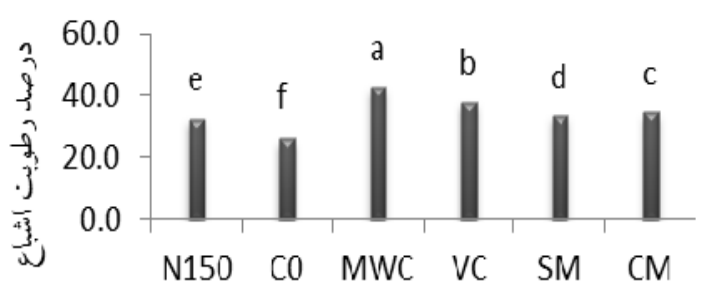

كود

شكل r. تأثير كودهاى آلى و اوره بر ميزان رطوبت اشباع خاك

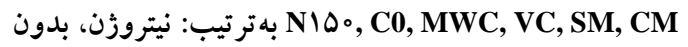

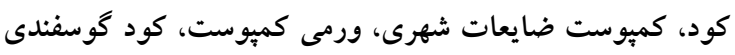
و كود كاوى. ميانخين هاى با حروف مشابه براساس آزمون در سطح ه درصد داراى اختلاف معنى دار نمى باشند

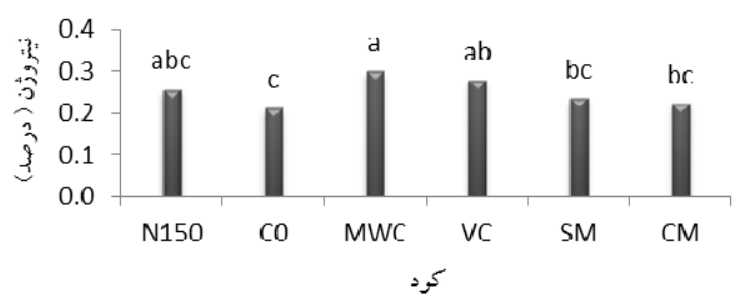

شكل ؟. تأثير كودهاى آلى و اوره بر مقدار نيتروزن كل (درصد) خاك. N10॰, C0, MWC, VC, SM, CM به ترتيب: نيتروزن، بدون كود، كميوست ضايعات شهرى، ورمى كميوست، كود

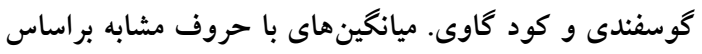
آزمون LSD در سطح ه درصدداراى اختلاف معنى دار نمى باشند ماند

(ج<०/०D)

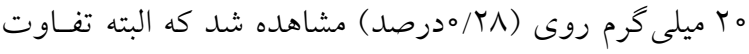

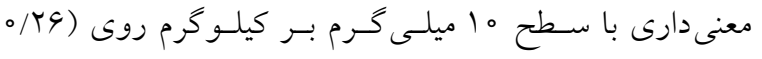

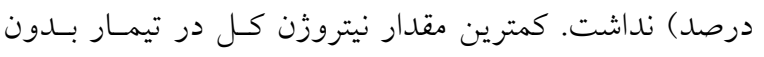

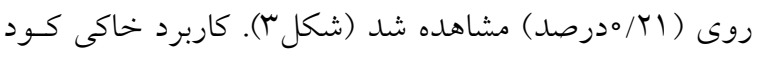
روى، موجب افزايش جذب نيتروزن شد (rV). كودهاى آلى مونى

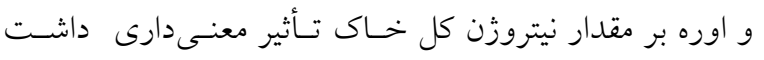

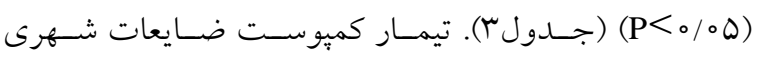
(م/\%/ درصد) بيشترين مقدار نيتروزن كل را داشت. كمتـرين

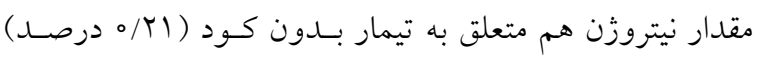

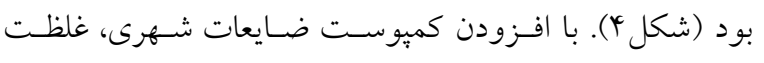

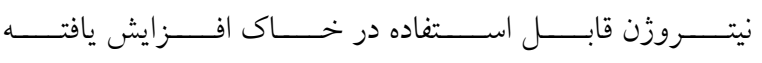

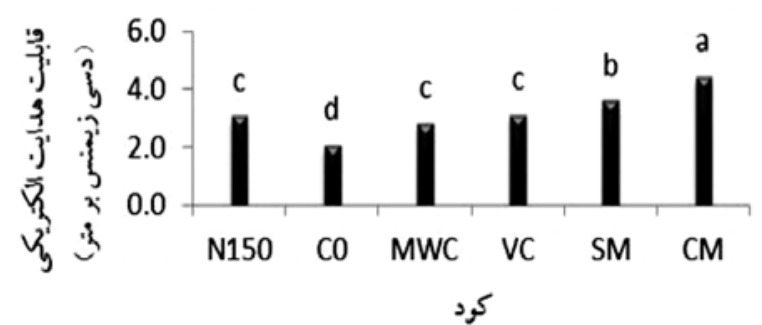

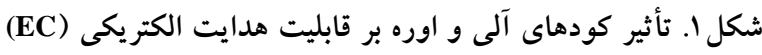
خاك. N10॰, C0, MWC, VC, SM, CM به ترتيب: نيتروزن، بدون

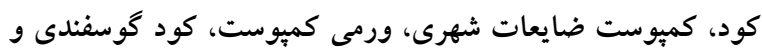
كود گاوى. ميانگينهاى با حروف مشابه براساس آزمون LSD در كرد سطح ه درصد داراى اختلاف معنى دار نمى باشند

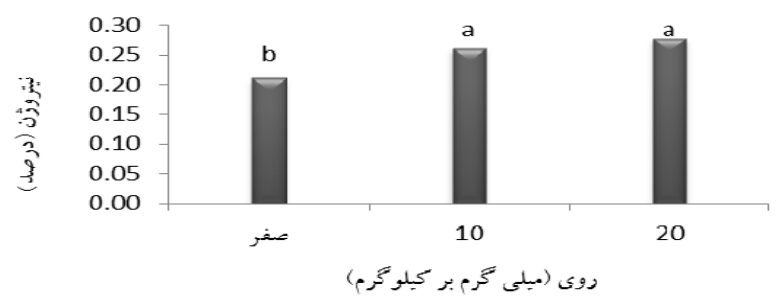

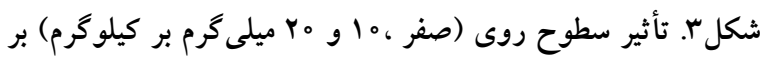

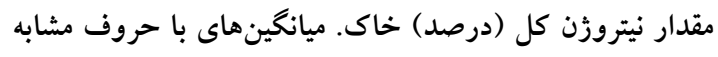
براساس آزمون LSD در سطح ه درصد معنى دار نمى باشند

داشت. كمترين درصد رطوبت اشباع در تيمار بدون كـود (به/A9 درصد) مشاهده شد (شـكل Y). تيمـار كميوسـت درصــ رطوبـت

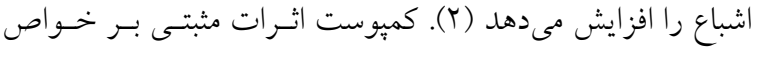

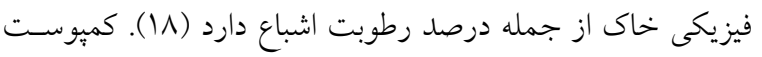

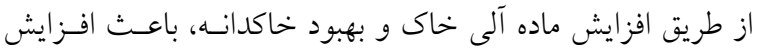

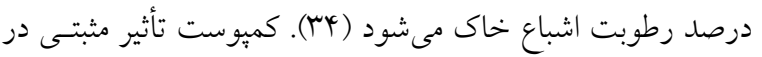

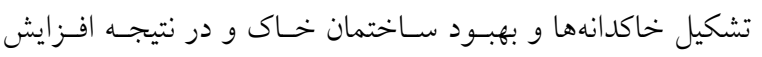
تخلخل و منافذ درشت خاك مىشود كه در نتيجـه ميـز ان درصــ رطوبت اشباع خاك را افز ايش مىدهد (1). مقدار نيتروزن كل خاك

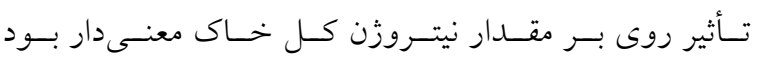




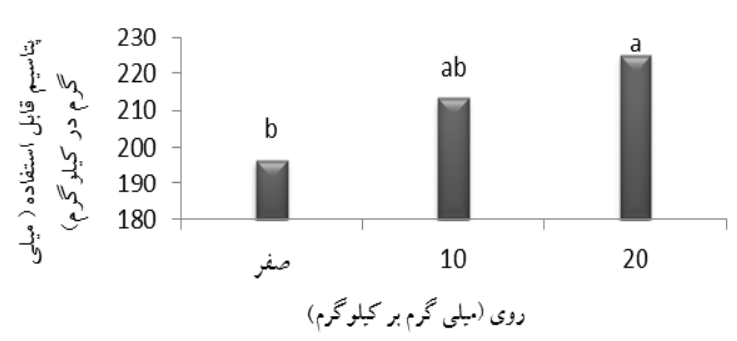

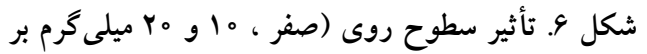

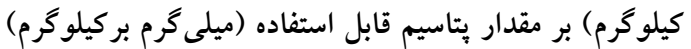

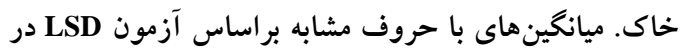
سطح ه درصد معنى دار نمى باشند

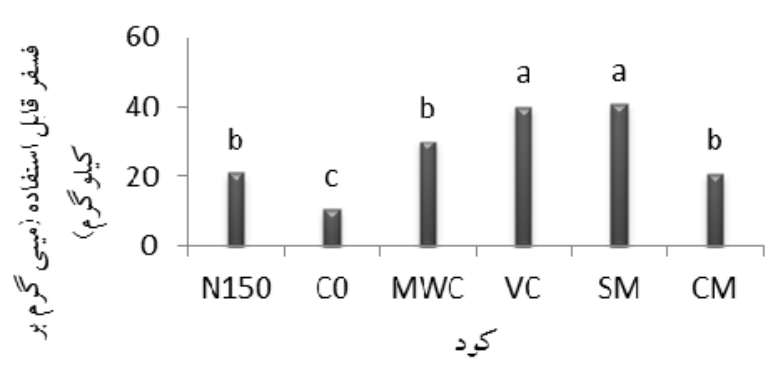

شكل ه. تأثير كودهاى آلى و اوره بر مقدار فسفر قابل استفاده (ميلى

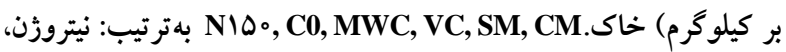

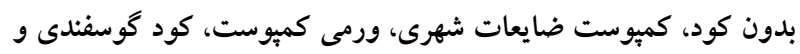

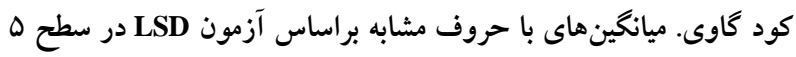
درصد داراى اختلاف معنىدار نمىباشند

است (9). جاكديو و همكاران اثر باقىمانده كمبوسـت در تنـاوب كُندم - برنج بررسى كردند و اظهارنمودند كه با مصرف كميوست ونست

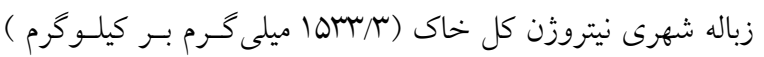

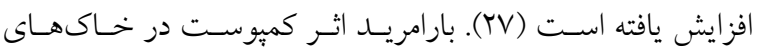

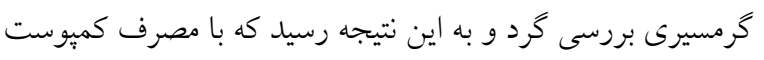

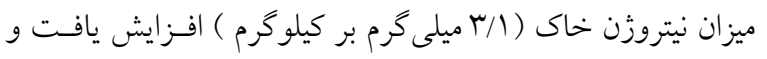

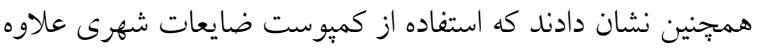

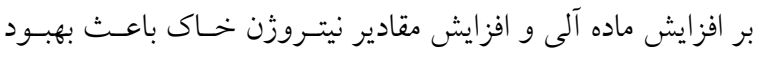
حاصل خيزى خاك نيز مىشود (Y.). مقدار فسفر قابل استفاده خاك

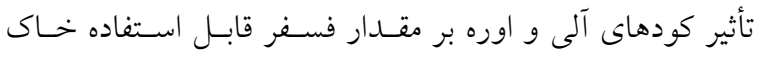
معنى دار بود) ميلى گرم در كيلو گرم) بيشترين مقـدار فسـفر قابـل اسـتفاده در

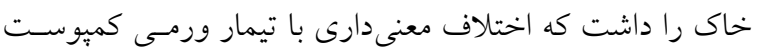

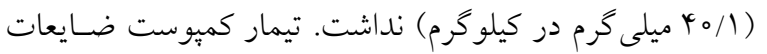

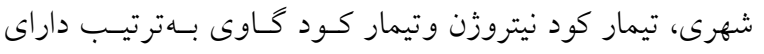

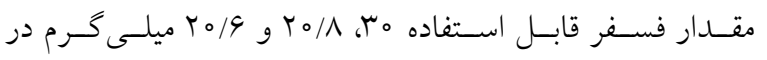
كيلوكرم بودند كه تفاوت معنى دارى بـا هـــم نداشـتند. كمتـرين

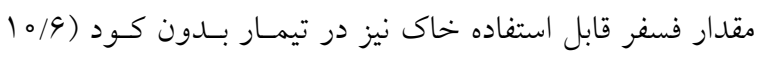

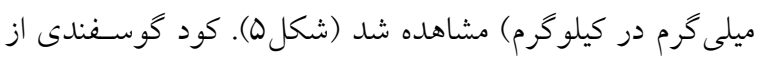



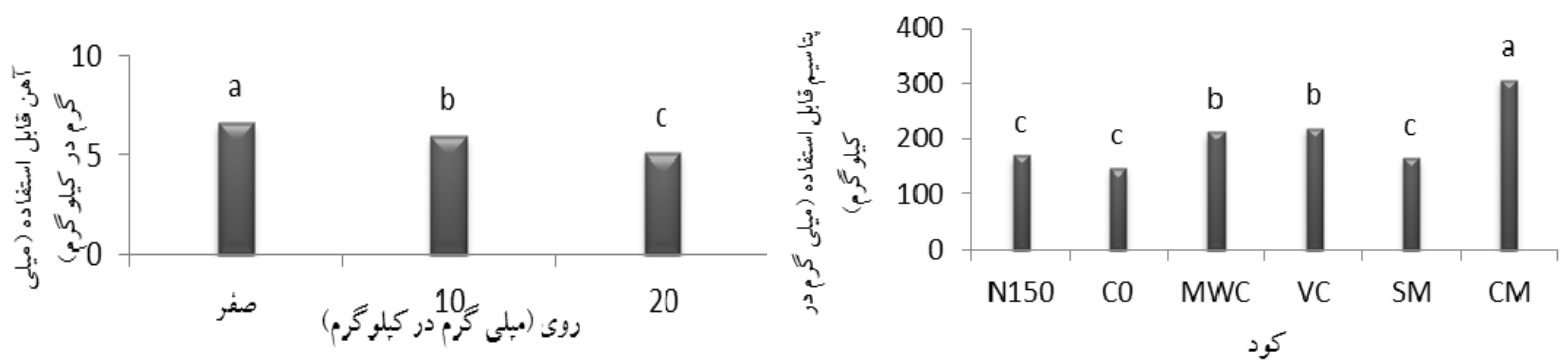

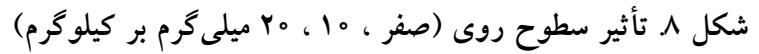
بر مقدار آهن قابل استفاده (ميلى گرم بر كيلو گرم) خاك.

شكل V. تأثير كودهاى آلى و اوره بر مقدار بتاسيم قابل استفاده (ميلى گرم

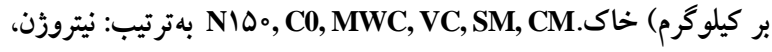

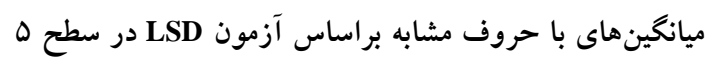
درصد معنى دار نمىباشند

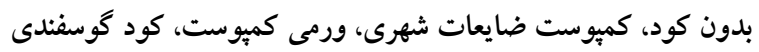
و كود كاوى. ميانگينهاى با حروف مشابه براساس آزمون LSD درد سطح ه درصدداراى اختلاف معنى دار نمى باشند

جدول f. ميانگين مربعات عناصر كم نياز و برخى ويزگى هاى فيزيكى خاك تحت تأثير عوامل مختلف مورد مطالعه

\begin{tabular}{|c|c|c|c|c|c|}
\hline منخنز & آهن & مس & روى & درجه آزادى & منابع تغييرات \\
\hline$r Y / D 19^{* *}$ & l/IVGns & $0 / 19 \mathrm{~V}^{\mathrm{ns}}$ & $10 / 1 \mu_{0}^{* *}$ & r & تكرار \\
\hline IIV/AOr & $10 / \Lambda r^{* *}$ & $\circ / \mu^{\prime} q^{n s}$ & $\Lambda F / V ৭ 9^{* *}$ & r & روى \\
\hline$r V / I V e^{* *}$ & $10 / 9 \Delta r^{* *}$ & $\varphi / r \mid I^{* *}$ & $M Y / / Q r^{* *}$ & 0 & كود \\
\hline$\Delta / V \mathscr{G} \mu_{\mathrm{ns}}$ & - $/ \Delta r \Delta^{n s}$ & ס & $r / V \mu_{0}$ ns & 10 & كود × روى \\
\hline$r / 9 V Q$ & - IfVG & $0 / I T V$ & $r / T \circ \varphi$ & ry & خطا \\
\hline
\end{tabular}

مقدار آهن قابل استفاده خاك

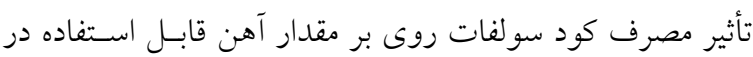

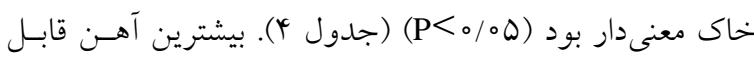

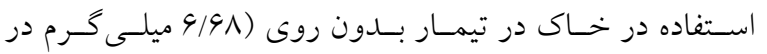

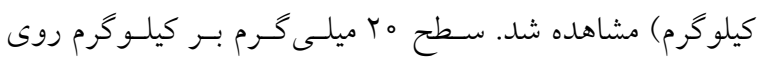

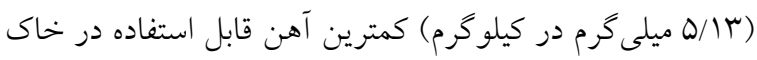

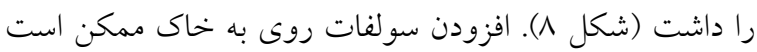

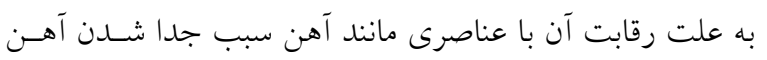

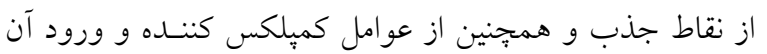

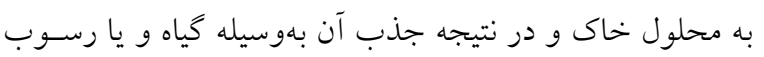

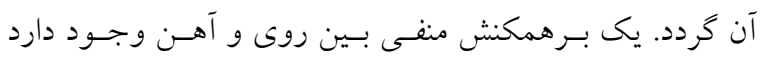

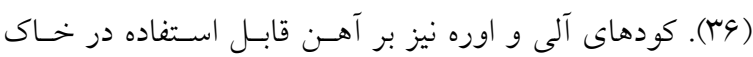

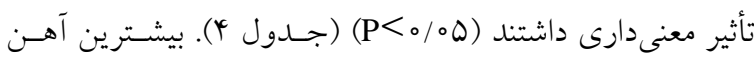

بيشترين مقدار يتاسيم قابـل اسـتفاده در خـاك در تيمـار كـود

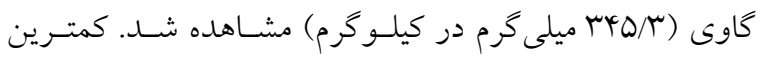

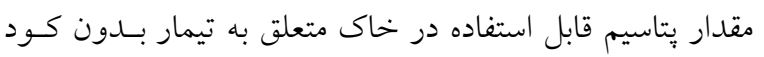

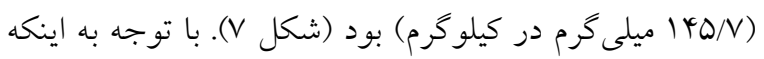

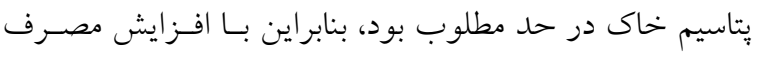

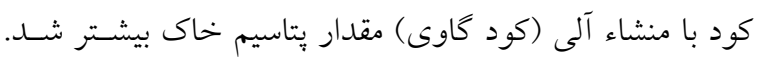

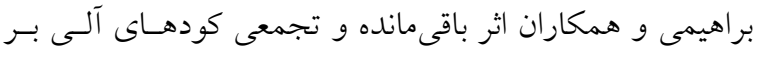

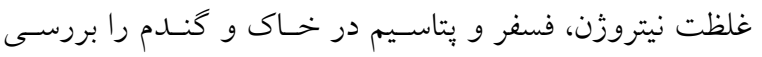

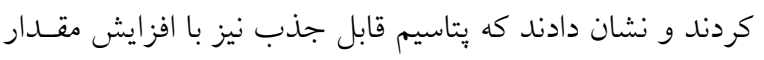

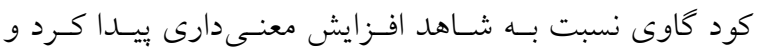

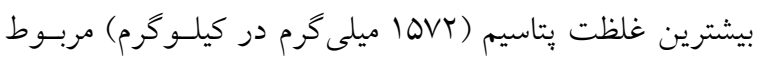
به تيمار ه ها تن كود كاوى مىباشد (r). 


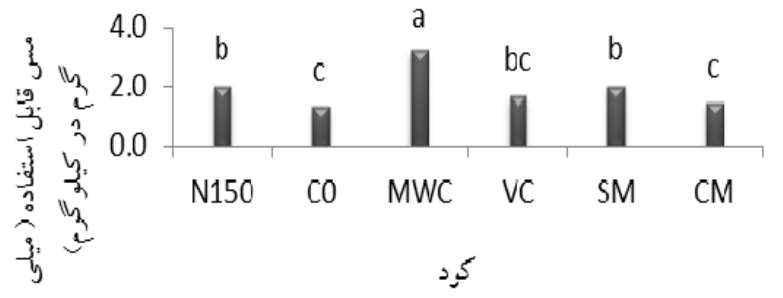

شكل ه ا. تأثير كودهاى آلى و اوره بر مقدار مس قابل استفاده (ميلى كرم بر كيلوكرم)خاك.N10॰, C0, MWC, VC, SM CM بهترتيب: نيتروزن،

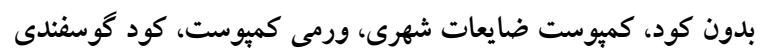

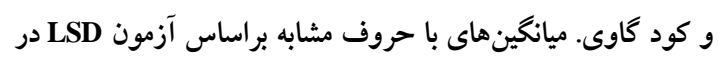

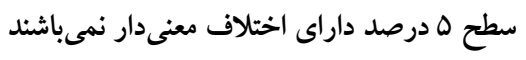

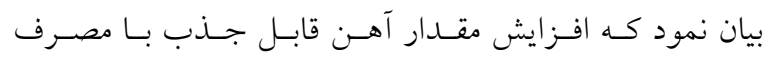

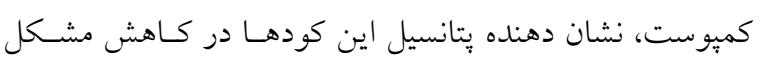

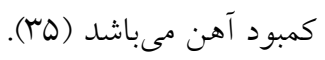

مقدار مس قابل استفاده خاك

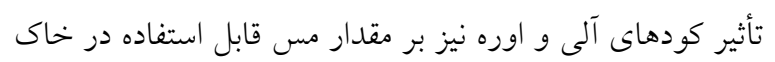

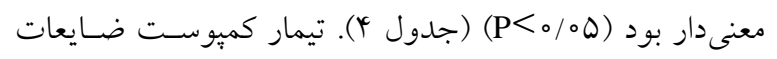

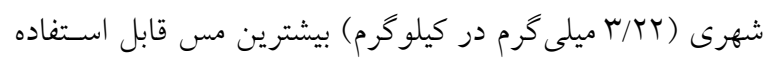

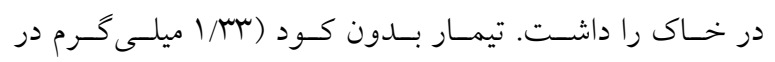

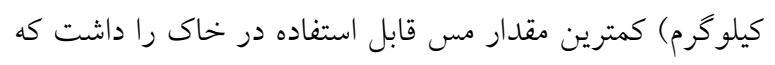

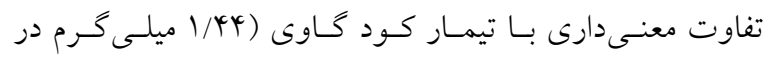

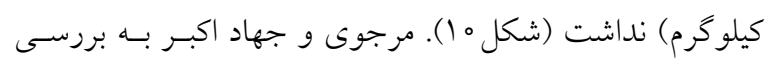
اثرات كميوست شهرى بر خصوصيات شيميايى خاك و صفات

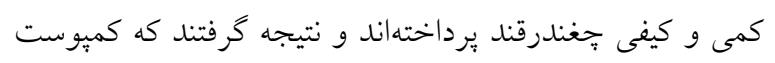

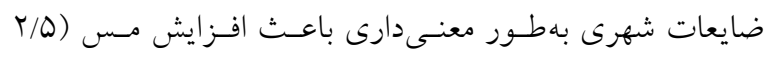

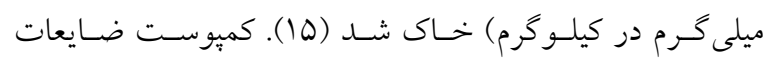
شهرى حاوى مقادير فراوانى عناصر معلنى است كه از مهمترين

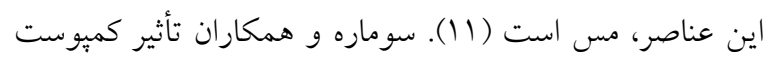

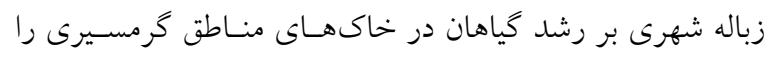

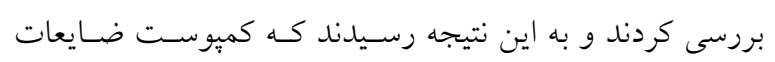

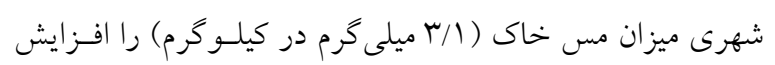

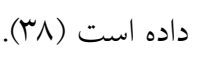

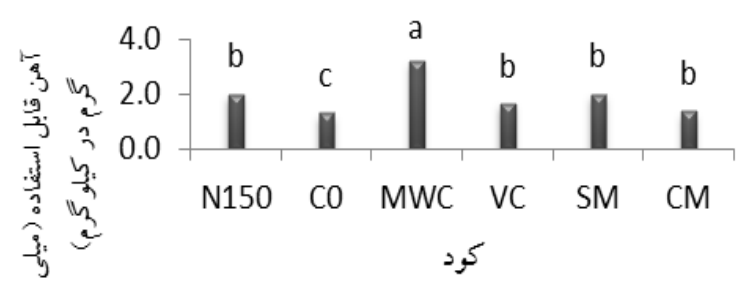

شكل 9. تأثير كودهاى آلى و اوره بر مقدار آهن قابل استفاده (ميلى

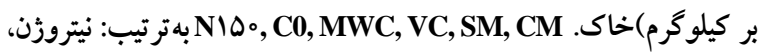
بدون كود، كمبوست ضايعات شهرى، ورمى كميوست، كود كو سفندى

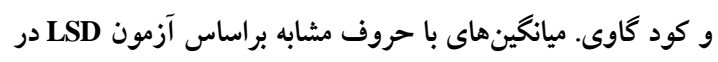

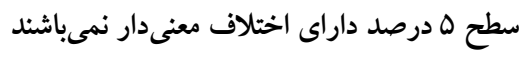

قابل استفاده در خاك در تيمار كميوست ضايعات شهرى V/V)

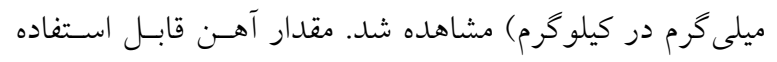

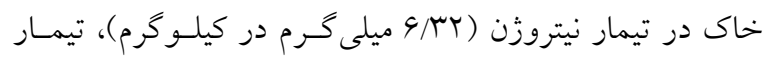

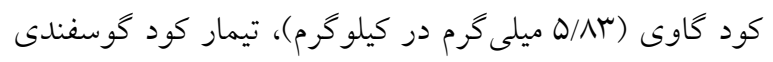

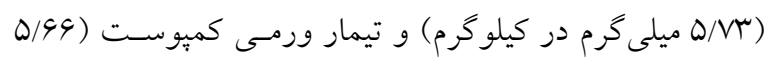

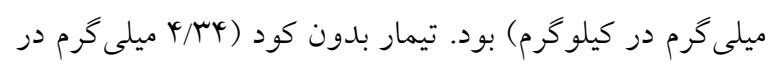

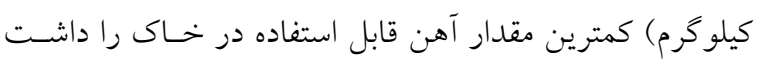

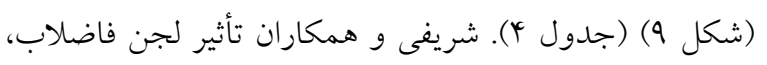

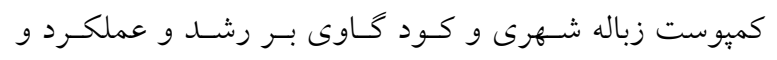

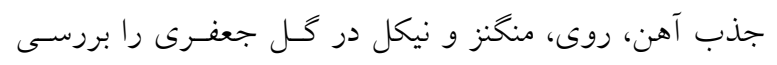

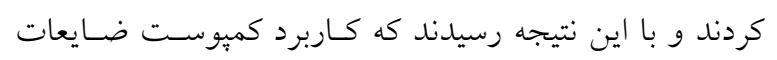

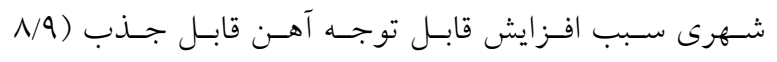

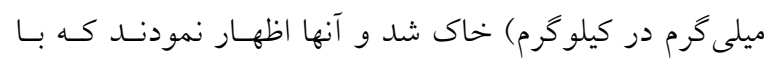

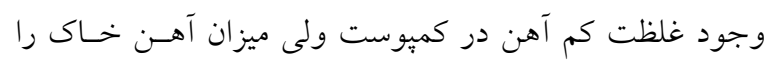

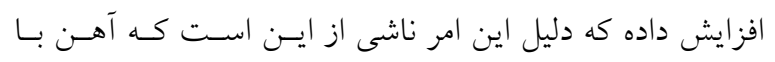

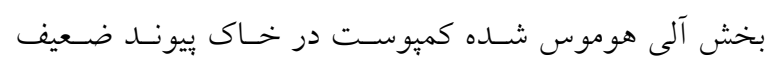

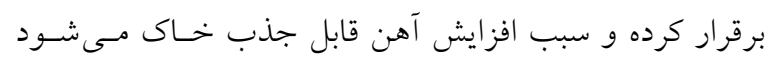

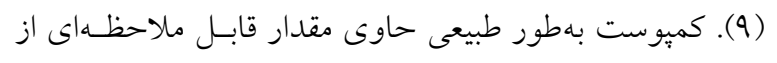

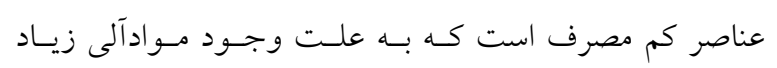

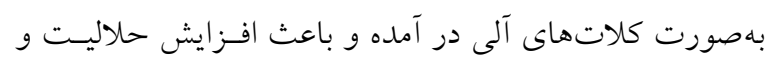

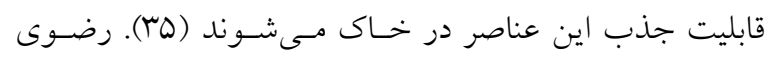

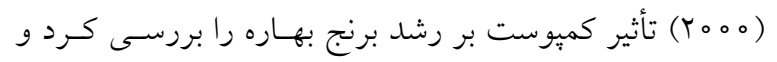




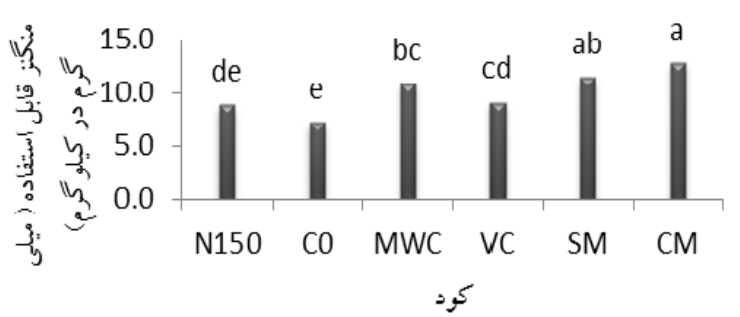

شكل Y1. تأثير كودهاى آلى و اوره بر مقدار مس قابل استفاده (ميلى گرم بر كيلو گرم) خاك.N1هo, C0, MWC, VC, SM CM بهترتيب: نيتروزن، بدون كود، كميوست ضايعات شهرى، ورمى كميوست، كود كو سفندى

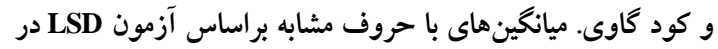
سطح ه درصد داراى اختلاف معنىدار نمىباشند

قابل استفاده خاك را داشت. كمترين مقدار روى قابـل استففاده خاك هم مربوط به تيمار بدون روى (ه ميلى گرم در كيلـوكرم)

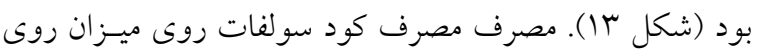

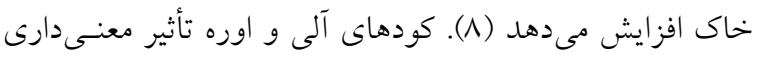

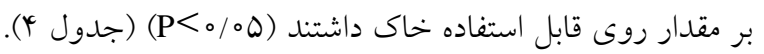
بيشـترين مقــدار روى قابـل اسـتفاده خــاك مربـوط بــه تيمـار كمبوست ضايعات شهرى (1اميلى گرم در كيلوكرم ) بود. تيمار بدون كود (ه/9 ميلى گرم بر كيلو گرم) كمترين مقدار روى قابـل فيل

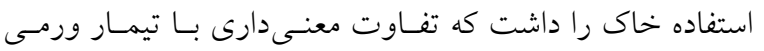

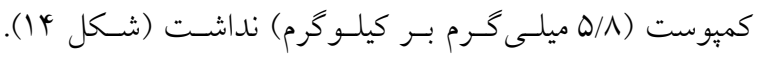

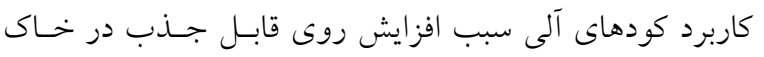

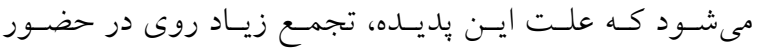

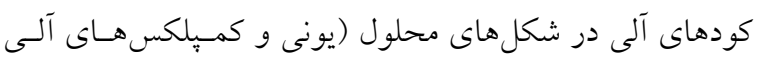

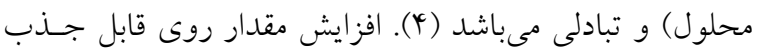

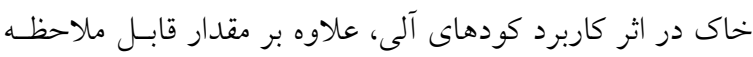

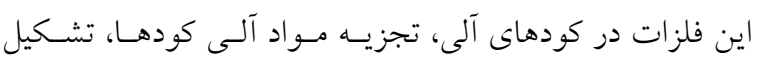

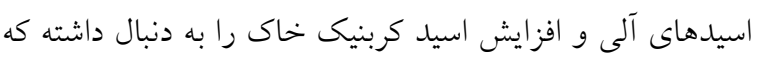

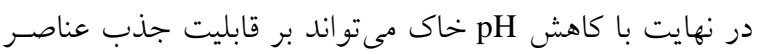

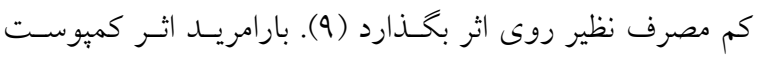

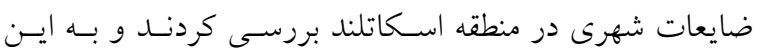

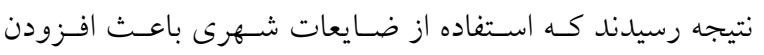

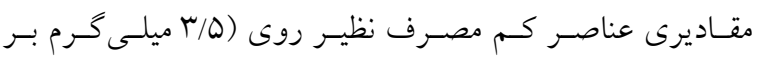

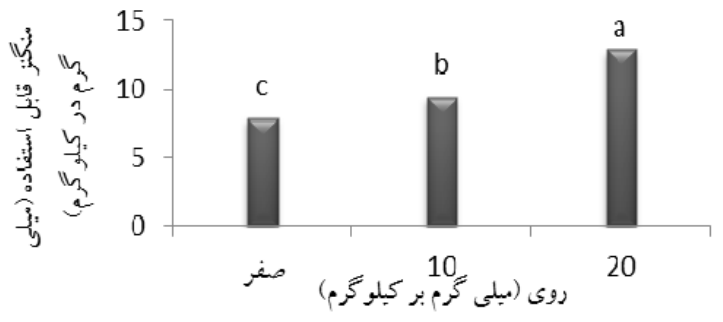

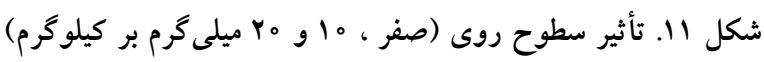
بر مقدار منگنز قابل استفاده (ميلى كرم بر كيلو كرم) خاك.

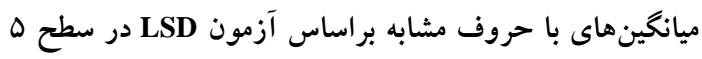
درصد معنى دار نمىباشند

مقدار منكنز قابل استفاده خاك

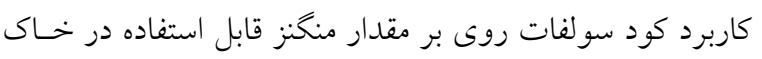

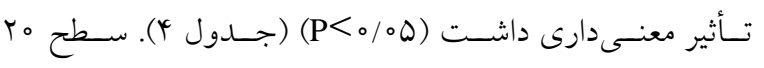

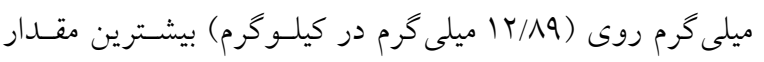

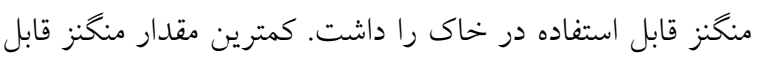

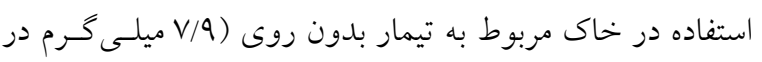

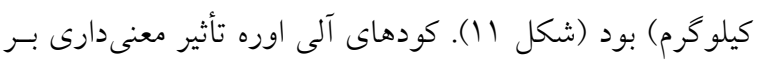

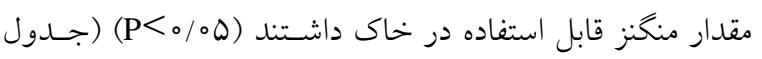

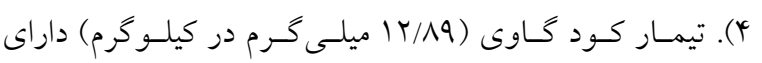

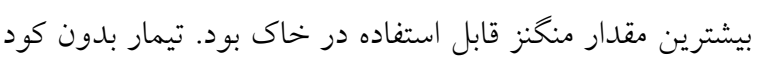
(ميلى كرم در كيلو كرم) V/TY) در خاك را داشت (شكل r I ). كودهاى حيوانى علاوه بر اثرات

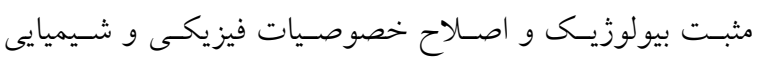

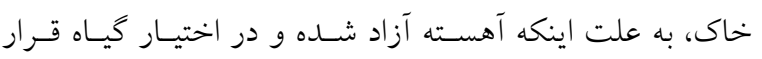

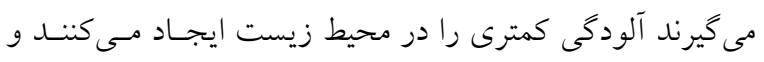

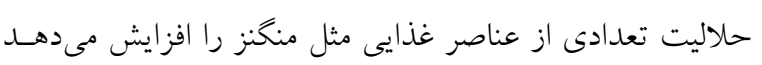
مقدار روى قابل استفاده خاى تأثير مصرف كود سولفات روى بــر مقـدار روى قابـل اسـتفاده

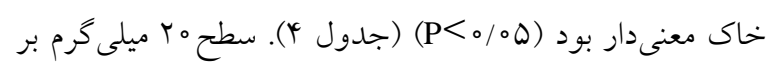

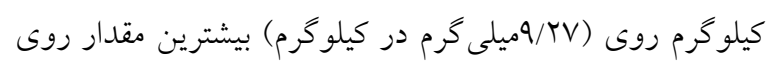




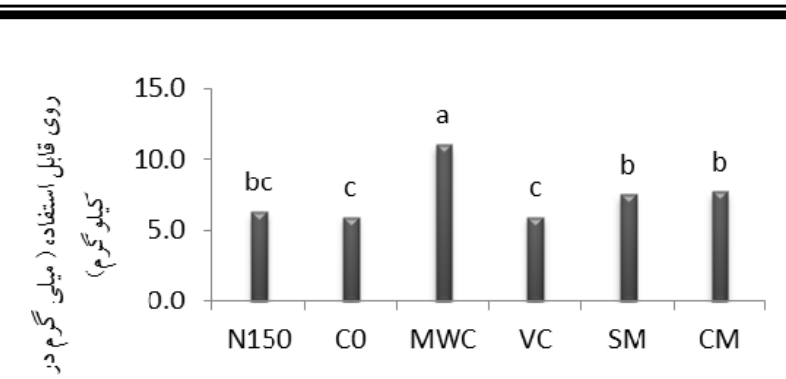

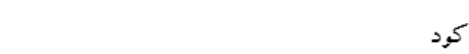

شكل 14. تأثير كودهاى آلى و اوره بر مقدار روى قابل استفاده (ميلى كرم

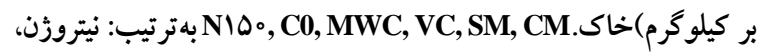
بدون كود، كميوست ضايعات شهرى، ورمى كميوست، كود كوسفندى

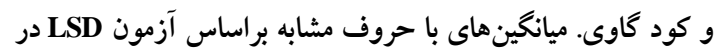

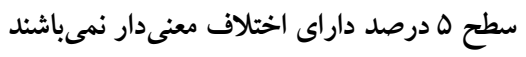

ظرفيت تبادل كاتيونى و در نتيجه جذب عناصر غذايى بهصسورت

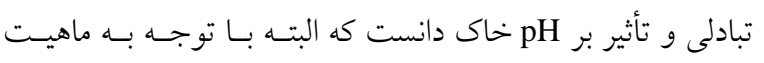

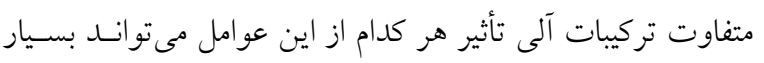

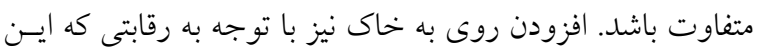

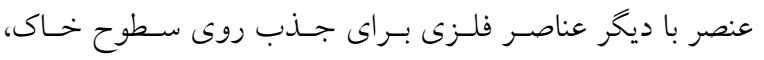

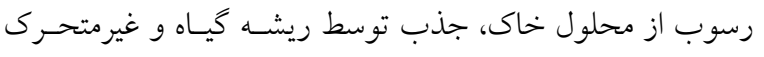

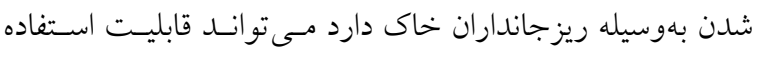

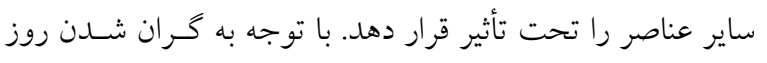

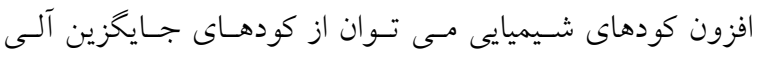

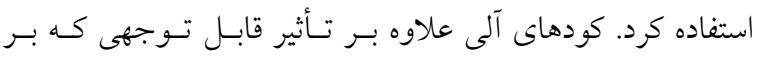

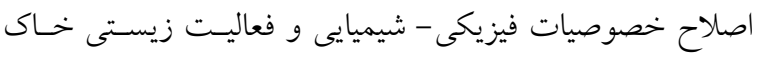

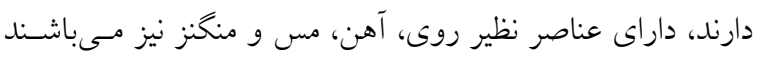

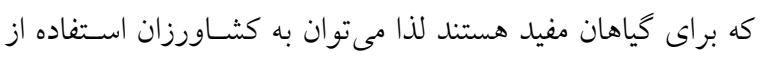

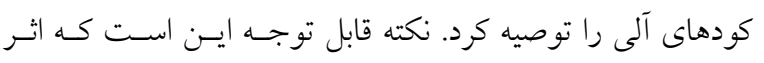

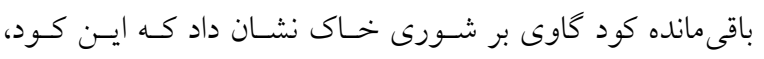

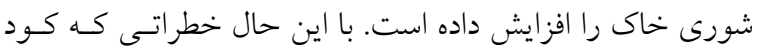
كاوى بر املاح محلول خاك دارد بايستى درنظر داشت و بيشن بينهاد مىشود اين موضوع در مطالعات آينده بررسى كردد.

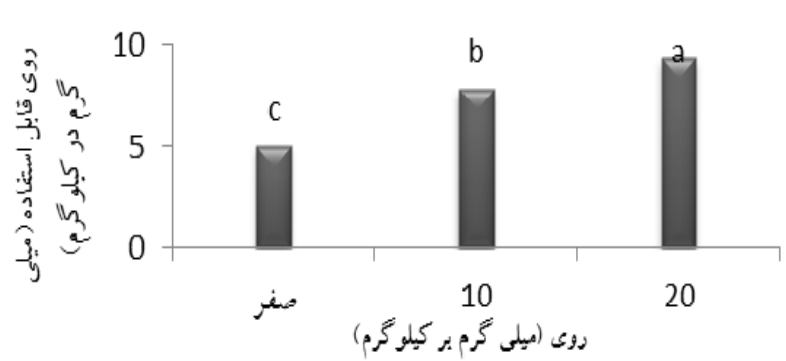

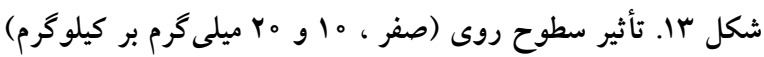

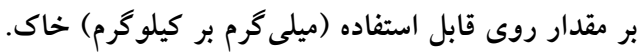

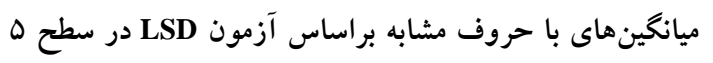
درصد معنى دار نمىباشند

كيلو گرم) به خاك شد كه اين امر منجر به بهبود حاصـل خيـزى

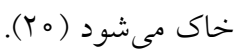

\section{نتيجه گيرى كلى}

بلهور كلى مىتوان نتيجه كيرى كرد كه كودهاى آلى بــه انـدازه و

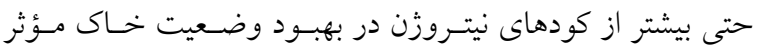

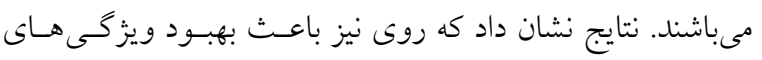

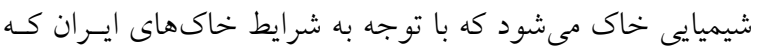

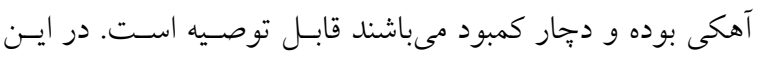

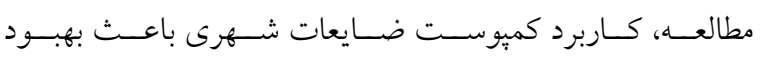

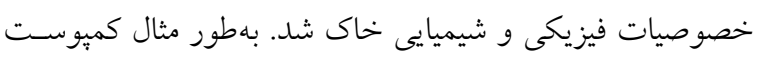

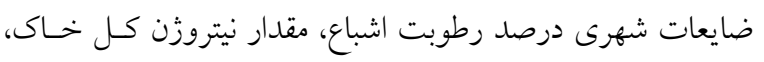

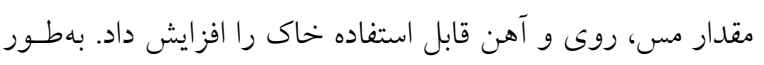

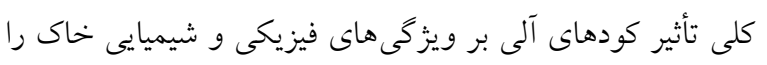

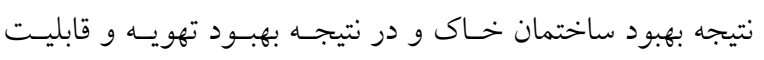

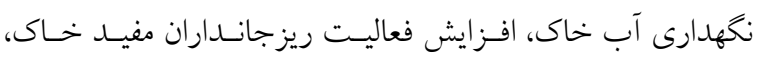

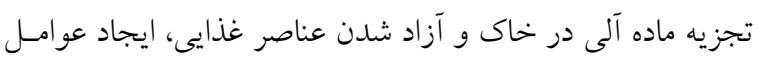

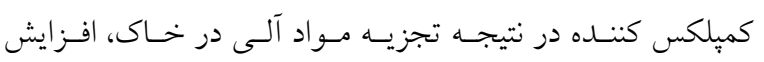




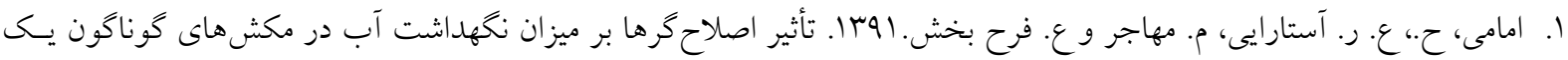

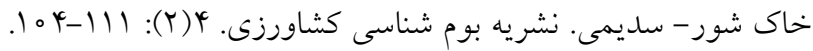

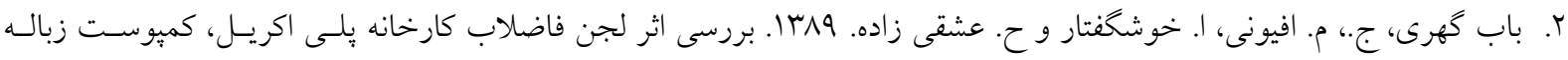

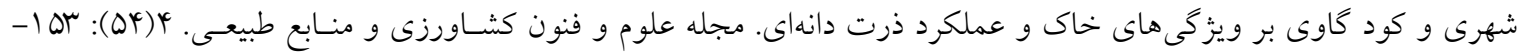

r. براهيمى، نويد.، م. افيونى، م. كرمى و ى. رضايى نزاد.

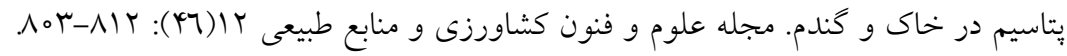

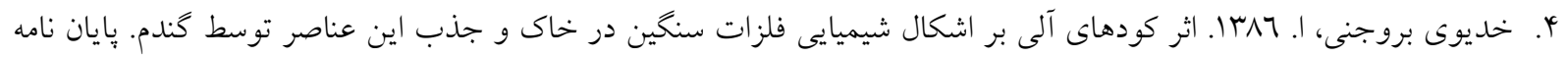
كارشناسى ارشد خاك شناسى. دانشكدة كشاورزى. دانشكاه صنعتى اصفهان.

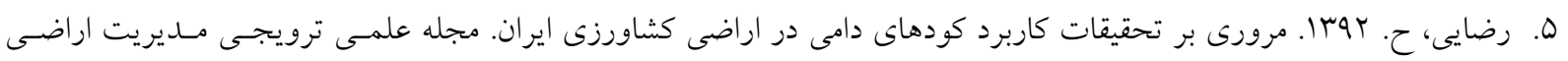
.07- $1(1) 1$

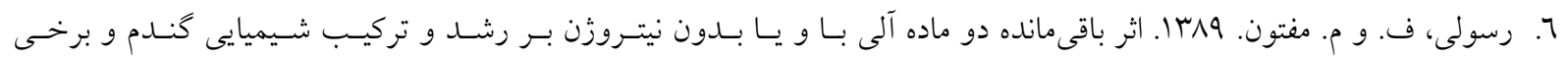

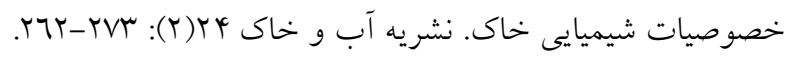

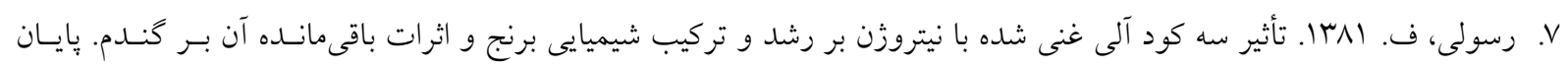
نامه كارشناسى ارشد خاكشناسى. دانشكدة كشاورزى، دانشخاه شيراز.

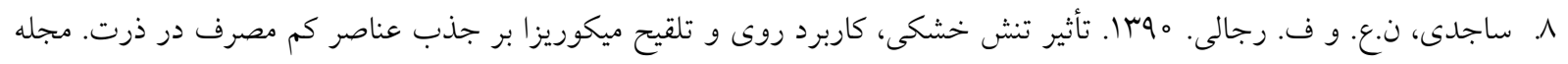

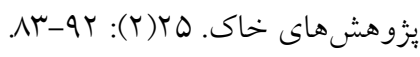

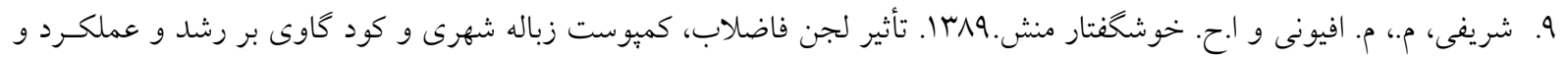

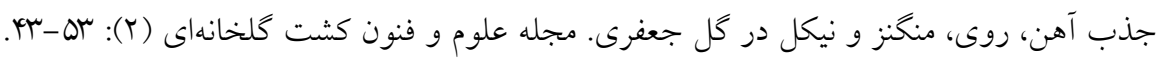

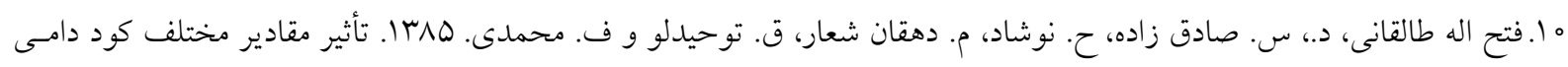

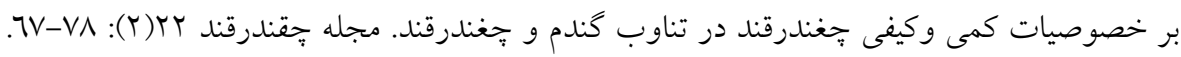

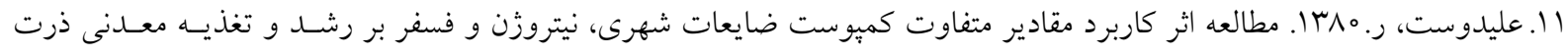

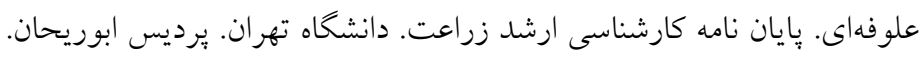

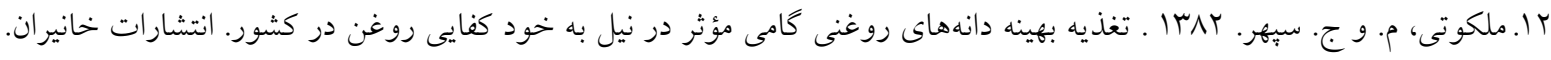

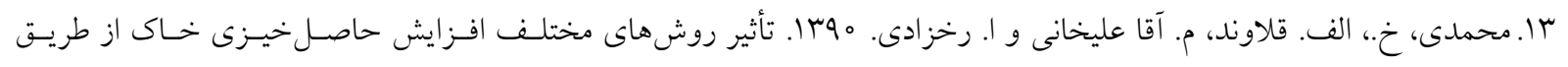

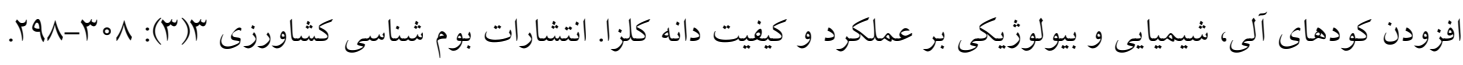

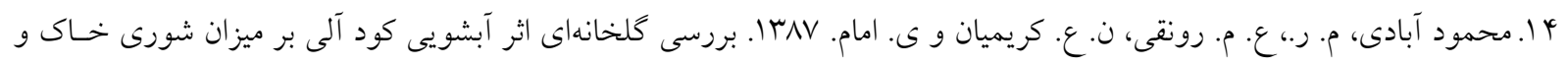

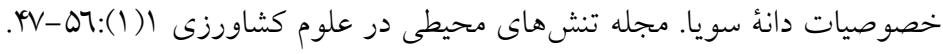

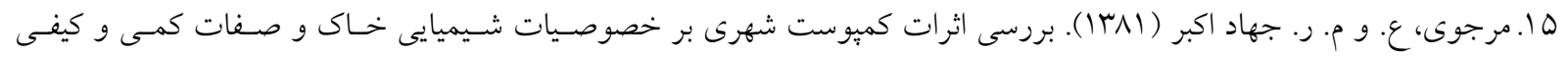

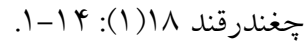

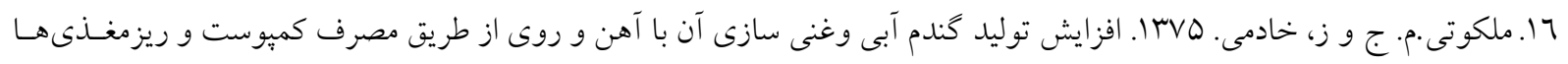




$$
\begin{aligned}
& \text { در ايران. نشر آموزش كشاورزى كرج، ايران. }
\end{aligned}
$$

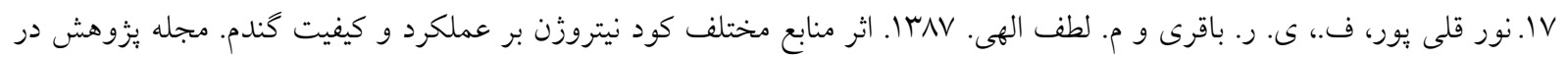

$$
\begin{aligned}
& \text { علوم كشاورزى ب (r): }
\end{aligned}
$$

18. Aggelides, S. M. and P. A. Londra. 2000. Effects of compost produced from town wastes and sewage sludge on the physical properties of a loamy and a clay soil. Bioresour.Technol. 71: 253 - 259.

19. Barbarik, K. A., J. A. Ippolito and D. G. Westfall. 1998. Extractable trace elements in the soil profile after years of biosolid application. J. Environ. Qual. 27: 801 - 805.

20. Bramryd, T. 2001. Effect of liquid and dewatered sewage sludge applied to a Scot pine stand (Pinus sylvestris L.) in central Sweden. For. Ecol. Manage. 147: 197 - 216.

21. Bremner J. M. 1965. Total nitrogen. PP. 1149-1178. In C. A. Black et al. (Ed.) Methods of soil analysis. American. Society. Agron., Madison, WI.

22. Casado-Vela, J., S. Selles, J. Navarro, M. A. Bustamante, J. Mataix, C. Guerrero, and I. Gomez. 2006. Evaluation of composted sewage sludge as nutritional source for horticultural soils. Waste. Manage. 26: 946-952.

23. Lindsay. W. L. and W. A. Norvel. 1978. Development of DTPA soil- test for zinc, iron and copper. Soil Sci. Soci. Am. J. 42: $421-428$.

24. Esmaeili, A., M. R. Mahmoodabadi, N. Karimian, A. Fotovat. 2008. Effect of manure and compost on growth and chemical composition of plant in two calcareous soils. $12^{\text {th }}$ Congress of Soil Science Pakistan. October 20-23.

25. Graham R. D., J. S. Ascher and S. C. Hynes. 1992. Selecting zinc - efficient cereal genotypes for soils of low zinc status. Plant Soil. 146: 241 - 250.

26. Hao, X. and C. Chang. 2003. Does a long term heavy cattle manure application increase salinity of a clay loam soil in semiarid southern Alberta. Agric. Ecol. Environ. 94: 89 - 103.

27. Jagdev S., C. R. Sharma and J. Sharma. 1997. Direct and residual effects of compost enriched mussoorioe rock phosphate in wheat-rice sequence. Indian J. Agric. Sci. 67: 192 - 198.

28. Khoshgoftramanesh, A. H. and M. Kalbasi. 2002. Effect of municipal waste leachate on soil properties and growth and yield of rice. Commun Soil Sci. Plant Anal. 33: 2011 - 2020.

29. Khayyat, M., E. Tafazoli, S. Rajaee, M. Vazifeshenas, M. R. Mahmoodabadi and A. Sajjadinia. 2009. Effects of $\mathrm{NaCl}$ and supplementary potassium on gas exchange, ionic content, and growth of salt-stressed strawberry plants. JPlant Nutr. 32: $1-12$.

30. Maskina, M. S., C. S. Khind and O. P. Meelu. 1986. Organic manures as a nitrogen source in a rice-wheat rotation. Int. Rice Res. News. 11: 44 - 49.

31. Mirzaei, R., J. Kambozia, H. Sabahi and A. Mahdavi. 2009. Effect of different organic fertilizers on soil physicochemical properties, production and biomass yield of tomato (Lycopersicon esculentum). Iran J. Crops Res. 7(1): 257-267.

32. Neeson, R. 2004. Organic processing tomato production. NSW Agriculture. Agfact. H. 8. 3. 6.Nyamangara, J. and J. Mzezewa. 2001. Effect of long-term application of sewage sludge to a grazed pasture on organic carbon and nutrients of clay soil in Zimbabwe. Nutr. Cycl. Agroecosys. 59: 13 - 18.

33. Olsen, S. R., C. V. Cole, F .S. Watanabe and C. A. Dean. 1954. Estimation of available phosphorous in soils by extraction with sodium bicarbonate. Soil Sci. Society of Am. J. 21: 144 - 149.

34. Ojeda, G., J. M. Alcaniz and O. Ortiz. 2003. Runoff and losses by erosion in soils amended with sewage sludge. Land Degrad Dev. 14: 563- 573.

35. Razavi Toosi, A. 2000. Interaction effects of compost, compost leachate and $\mathrm{Mn}$ on growth and chemical composition of spinach and rice seedling. M.Sc. Thesis, College of Agriculture, Shiraz University, Iran.

36. Savaghebifirouozabadi, G. h., M. J. Malakouti and M. Avdalan. 2003. Available of different form of sulphur fertilizer on wheat and oil grain rape. Plant and soil. Iranian J. Agric. Sci. 34(2) : 471 - 482.

37. Saeedi, G. H. 2008. The effect of some macro and microelements on grain yield and other agronomic characters on (Sesamum indicumL.). JSci. Technol. Agric. Nat. Res. 45: 379-402.

38. Soumare, M., F. M. G. Tack and M. G. Verloo. 2003. Effects of a municipal solid waste compost and mineral fertilization on plant growth in two tropical agricultural soils of Mali. Bioresour. Technol. 86: 15 - 20.

39. Sabahi, H., A. Ghalavand, A. M. ModarresSanavy and A. Asgharzadeh. 2008. Comparing the effects of integrated and conventional fertilization systems on canola (Brassica napus) yield and chemical properties of soil. Water Soil J. 22(2): 1-15.

40. Takkar, P. N. and C. D. Walker. 1993. The distribution and correction of Zinc deficiency. PP: 151-166. In: Robson, A. D. ( Ed.), Zinc in soils and plants. Kluwer academic Publishers, Dordrecht, the Netherlands.

41. U. S. Salinity Laboratory. 1954. Diagnosis and improvement of saline and alkali soils. USDA Handbook No:60. 


\title{
Evaluation of Persistence Impact of Organic Amendments, Urea Nitrogen and Zinc Sulphate Application on Soil Characteristics in Rapeseed-wheat Rotation
}

\author{
S. Moradnia ${ }^{1}$, R. Naderi ${ }^{* 1}$ and M. Najafi ${ }^{2}$
}

(Received: June 12-2015 ; Accepted: Oct. 03-2016)

\begin{abstract}
In order to investigate the persistence of organic amendments, nitrogen and zinc effects on soil characteristics in rapeseed-wheat rotation, a factor analysis was conducted in a complete random design with three replications in two consecutive years in a greenhouse. Treatments in the first year consisted of $\mathrm{N}$ fertilizer, municipal waste compost, vermicompost, sheep manure. The control consisted of zinc and two rapeseed cultivars. In the second year of the experiment, two cultivars of durum wheat were sown in the same pots as the first year of the experiment. Results showed that two years after application of cattle manure, a significant increase in soil electrical conductivity (41.81\%), available K (59.45 \%) and available Mn (79.82 \%) compared to the control were found. Saturated soil moisture (48.57\%), total N (94.66 \%), available Fe (46.49 \%) and available Cu (47.51 \%) significantly increased by municipal waste compost compared to the control. Also, Zinc had a significant effect on soil total N (0.28 \%), available K (218.4 $\mathrm{mg} / \mathrm{kg})$ and available Mn $(12.89 \mathrm{mg} / \mathrm{kg})$. Generally, the results showed that application of organic amendments can change many soil characteristics which some of their impacts might last for next upcoming years. Therefore, it is necessary to monitor the soil characteristics and nutrients availability of the fields that were treated with organic amendments in the years after application.
\end{abstract}

Keywords: Organic amendments, Compost, Animal manure, Sustainable agriculture.

1.Dept. of Agroecology, College of Agric. and Natural Resour. of Darab, Shiraz Univ., Shiraz, Iran.

2.Dept. of Soil Sci., College of Agric. and Natural Resour. of Darab, Shiraz Univ., Shiraz, Iran.

*: Corresponding Author, Email: Naderi.ruhollah@gmail.com, rnaderi@shirazu.ac.ir 